\title{
STEREOTYPES AGAINST FEMALE ONLINE OJEK DRIVERS IN SURAKARTA CITY
}

\author{
Shinta Rosalina \\ Program Studi Pendidikan Sosiologi Antropologi, FKIP, Universitas Sebelas Maret, e-mail: shintarosa47@gmail.com \\ Nurhadi \\ Program Studi Pendidikan Sosiologi Antropologi, FKIP, Universitas Sebelas Maret, e-mail: nurbadi@staff.uns.ac.id \\ Yuhastina \\ Program Studi Pendidikan Sosiologi Antropologi, FKIP, Universitas Sebelas Maret, e-mail : yubastina@gmail.com
}

(C2021 by the authors. Submitted for possible open access publication under the terms and conditions
of the Creative Commons Attribution-ShareAlike 4.0 International License (CC-BY-SA)
license (https:// creativecommons.org/licenses/by-sa/4.0/)
DOI: $\underline{\text { bttp://dx.doi.ong/10.30983/ bumanisme.v5i1 }}$

\begin{abstract}
This study investigated the stereotypes of female online motorcycle taxi drivers, who pinned the stereotype of female online motorcycle taxi drivers, and why the stereotype of female online motorcycle taxi drivers in Surakarta emerged. This study used a qualitative method with a phenomenological approach. Sources of data used were primary data sources and secondary data sources-the data collected by interviews and observations. This study indicated that (1) The stereotype of online motorcycle taxi drivers arises from a sub-culture in a society where men are closely related to masculine characteristics while women are feminine. So, working as a driver in a society closely related to masculine people creates stereotypes for women. (2) In the process, the stereotype of female online motorcycle taxi drivers appeared in most of the people who interacted with them, such as customers, fellow online motorcycle taxi drivers, and their families. (3) The reason for the emergence of a stereotype among female motorcycle taxi drivers is that women's driving proficiency is not the same as men's. In general, women who drive on a man are considered less common in some societies. Especially if the female drivers still receive orders at night, some community members and fellow male drivers consider it to be precarious and endangering women.
\end{abstract}

Keywords: Discrimination, Female driver, Online transport, Stereotype.

\begin{abstract}
Abstrak
Penelitian ini bertujuan untuk mengetahui bagaimana stereotip driver ojek online perempuan, siapa yang menyematkan stereotip driver ojek, online perempuan dan mengapa stereotip driver ojek online perempuan di Kota Surakarta muncul. Penelitian ini menggunakan metode kualitatif dengan pendekatan fenomenologi. Sumber data yang digunakan adalah sumber data primer dan sumber data sekunder. Hasil dari penelitian ini menunjukkan babwa (1) Stereotip pada driver ojek online muncul dari adanya sub budaya dalam masyarakat bahwa laki-laki erat dengan sifat maskulin sedangkan perempuan dengan sifat feminim. Sehingga, ranah pekerjaan sebagai driver yang di masyarakat erat dengan kaum maskulin membuat munculnya stereotip pada perempuan. (2) Dalam prosesnya stereotip terbadap driver ojek. online perempuan muncul pada sebagian besar orang yang berinteraksi denganny seperti customer, rekan sesama driver ojek online dan keluarga. (3) Alasan munculnya sebuah stereotip pada driver ojek perempuan berkaitan dengan kemahiran dalam mengemudi perempuan tidak sama dengan kaum laki-laki. Secara umum perempuan yang memboncengkan seorang laki-laki dianggap kurang lazim bagi sebagian masyarakat.Terlebih jik a di malam haridriver perempuan yang masih gadis masih menerima orderan hal tersebut dianggap oleh sebagian masyarakat maupun dari teman sesama driver laki-laki sangat beresiko dan membahayakan diri perempuan.
\end{abstract}

Kata Kunci: diskriminasi, ojek daring, pengemudi perempuan, stereotip. 


\section{Introduction}

The Millennial Era has created competition in various aspects of life. In particular, it has had an impact on the lives of women, especially women. Globally, there is 48.5 percent of working women ${ }^{1}$. At the national level, World Bank data for 2020 shows that the participation rate of women in the world of work reaches 56 percent $^{2}$. Today, more and more women are taking up jobs that are traditionally seen as male professions ${ }^{3}$.

In the modern era, technology is developing rapidly-especially technology in information and communication that focuses on the use of smartphones. Smartphones provide a variety of applications to make daily activities more practical. Starting from the application of means of communication, e-commerce applications, e-banking applications, to applications for transportation service providers, and so on.

One of the developments in the field of technology is a transportation service provider. It is the era of online motorcycle taxis available on smartphones. As reported in the news, online motorcycle taxis contribute to creating new job opportunities in economic activities in various regions of Indonesia, one of which is the city of

\footnotetext{
1 International Labour Office, World Employment Social Outlook: Trends for Women 2018 Global Snapshot, International Labor Organization, 2018 $<$ http://www.ilo.org/wcmsp5/groups/public/--dgreports/---dcomm/--publ/documents/publication/wcms_619577.pdf>.

2 World Bank, 'Labor Force Participation Rate, Female (\% of Female Population Ages 15-64) (Modeled ILO Estimate) - Indonesia', 2020 $<$ https://data.worldbank.org/indicator/SL.TLF.AC TI.FE.ZS?locations $=$ ID $>$.

${ }^{3}$ B Suyanto and E S Hendarso, Wanita Dan Subordinasi Dan Marjinalisasi Menuju Ke Pemberdayaan (Surabaya: Airlangga University Press, 1996).
}

Surakarta. Even so, at the beginning of the emergence of online motorcycle taxis, they also experienced rejection from the community because they were considered to be seizing income from conventional motorcycle taxi drivers ${ }^{4}$.

At first, in general, being an online motorcycle taxi driver was carried out by men. However, at this time, women also do not want to lose to explore jobs in online motorcycle taxis. The availability of these jobs makes women interested in becoming online motorcycle taxi drivers so that gender stereotyping terms emerge. These stereotypes have different forms from one society to another because of the norms, customs, beliefs, and habits of different people. $^{5}$

Gender stereotypes give rise to assumptions about treating a particular gender, but not necessarily by the truth. For example, in the Javanese community, especially Surakarta, women do not have much capacity in their roles in the public sphere, such as earning a living. Moreover, the job of being a driver is often carried out by a man. One of the steps to become a driver is to make their family fulfilled and prosperous, which is their goal to work. So that when families experience problems in terms of economy, women as wives, mothers, and children do not stay silent. They choose to work to meet the needs of the family.

Marginalization of women workers occurs in various sectors. For example, a study conducted in the city of Pekalongan showed that female workers in the batik industry earned lower wages than male

${ }^{4}$ Ant, 'Ojek Online Dilarang Beroperasi Di Solo’, News.Okezone.Com, 2016.

5 Bryan S Turner, The Cambridge Dictionary of Sociology, ed. by Bryan S Turner (New York: Cambridge University Press, 2006), p. 249. 
workers because they were seen as having lower skills ${ }^{6}$. The gender challenge faced by women online motorcycle taxi drivers is the struggle to recognize equal rights with men because working in jobs that men dominate is not easy for women. They are often underestimated because they are considered less capable when they receive orders that require them to deliver large items ${ }^{7}$.

Gender equality, many women do jobs that were previously only done by men, such as motorcycle taxi drivers. On the other hand, female online motorcycle taxi drivers provide an alternative for consumers who feel uncomfortable if a male motorcycle taxi driver carries them. With the old stereotypes still circulating in the environment, female online motorcycle taxi drivers can show their existence and quality to be equal to other online motorcycle taxi drivers, namely men. ${ }^{8}$ Data reported by one of the on-demand service platforms, namely Grab. Grab data shows that there was an increase in the number of female driver-partners in Indonesia by $490 \%$ in January 2018 compared to January 2017 .

${ }^{6}$ Rita Rahmawati, Shinta Dewi Rismawati, and Esti Zaduqisty, 'Sistem Pengupahan Dan Pembagian Kerja Perempuan Buruh Batik Berbasis Putting out System Di Kota Pekalongan (Proses Dan Implikasi Marginalisasi Terhadap Perempuan Buruh Batik)', Research Journal, 10.2 (2013), 274-93.

${ }^{7}$ Evie A A Tumimbang, Gladys N, Suwu and Juliana Tumiwa, 'Kajian Gender Tentang Pengemudi Go-Jek Perempuan Di Kota Manado', Jurnal Holistik, 13.3 (2020), 1-16.

${ }^{8}$ Irma Verasatiwi and Roro Retno Wulan, 'Studi Fenomenologi Pengemudi Ojek Online Perempuan Di Kota Bandung Dalam Kajian Feminisme', Journal Acta Diurna, 14.1 (2018), 91-99 $<$ https://doi.org/10.20884/1.actadiurna.2018.14.1.11 $45>$.

${ }^{9}$ Maizal Walfajri, Jumlah Mitra Pengemudi Perempuan Grab Indonesia Tumbuh Lima Kali Lipat', Industri.Kontan.Co.Id, 2018.
The inclusion of women working as online motorcycle taxi drivers does not always get a positive view from the environment and society. The assumption is that working as a motorcycle taxi driver is more suitable for men. As in an online news story that contains an opinion about female online motorcycle taxi drivers when they want to pick up passengers, female online motorcycle taxi drivers often get rejected, especially male passengers. ${ }^{10}$

Similar news contains about frequent cancellations because many male passengers think they are inferior when female online motorcycle taxi drivers are shaken, in addition to pity factors, unskilled motorbikes, discomfort, or reasons rooted in sexism and others. ${ }^{11}$ This is because of the stereotype that exists in society which says that women are weak creatures ${ }^{12}$. Stereotypes in society say that women are gentle, thus discriminating between suitable jobs for women and men. Thus, female online motorcycle taxi drivers will ultimately lead to positive and negative perceptions in society and families. It becomes a challenge for women in carrying out their profession as online motorcycle taxi drivers.

In this case, several relevant studies discuss the stereotypes of female online motorcycle taxi drivers. The selection of this relevant research is based on supporting or referencing the author's research data.

${ }^{10}$ Ridwan Arifin, 'Sedih! Driver Ojol Suka Ditolak Hanya Karena Perempuan', Oto.Detik.Com, $2018<$ https://oto.detik.com/berita/d4319439/sedih-driver-ojol-suka-ditolak-hanya-karenaperempuan $>$ [accessed 10 October 2019].

${ }^{11}$ Kanedi, 'Ketika Pengemudi Ojek Online Perempuan Di-'Cancel' Penumpang Lelaki', Www.Watyutink.Com, 2017.

12 Joanne Sharp and others, 'Doing Gender Development: Empowerment Understanding Relations Gender', Transactions of the Institute of British Geographers, 28.3 (2003), 281-95. 
Research on the existence of female online motorcycle taxi drivers as a form of gender equality is relevant to research that will be carried out by researchers related to female online motorcycle taxi drivers. The results of this study are that some women choose to become online motorcycle taxi drivers as a form of gender equality and consider that being an online motorcycle taxi driver is a fairly easy job to do either as a main or a side job. One of the main factors driving women to choose to work as online motorcycle taxi drivers, because they have the responsibility to support their children because of their status as single parents. ${ }^{13}$

Research on the estimation of gender equality in the women's online motorcycle taxi profession, which was conducted in Malang City, explained that the emergence of discourse for the context itself that the rationality of women choosing professions as online motorcycle taxis is not only for economic reasons but also for housing social dynamics that occur in society. Foucault argues that the phenomenon of gender can be regarded as a discourse that will later build the concept of a culture and culture. Idealism and romance, women need work not only as an economic demand but also a gender shift that women do not only take care of the housework. The choice to become an online motorcycle taxi driver is a "shortcut" to earn money for women with high work ethic. Moreover, it is supported by a new feature from the Grab application that later female passengers will get female drivers more often ${ }^{14}$.

${ }^{13}$ Alif Fadzilatus Siti Arofah and Yus'afin Taji Alam, 'Eksistensi Driver Ojek Online Perempuan Sebagai Bentuk Kesetaraan Gender', Jurnal Sosiologi Nusantara, $\quad 5.2 \quad$ (2019), $171-83$ $<$ https://doi.org/10.33369/jsn.5.2.171-183>.

${ }^{14}$ Siti Fatimah Soenaryo Kurniawan, Faisal, 'Menaksir Kesetaraan Gender Dalam Profesi Ojek
Research on online-based female public transportation drivers in East Jakarta using descriptive qualitative research methods concluded that the stereotypes they experience have two types, negative and positive. Negative stereotypes are the assumption that female drivers are not good at driving, emotional, not focused on work. Positive stereotypes such as gentle and natural in serving passengers, accustomed to much workload, and an inspirational figure for those around him. ${ }^{15}$

Research conducted in Surabaya using qualitative descriptive research methods and analysis using social construction theory on women's online motorcycle taxis concluded that the externalization process to objectification shows that online motorcycle taxi women interpret their profession as fulfilling their profession's economic needs for their family or themselves. Second, women interpret it as a profession that has a comfortable work environment. The surrounding environment plays a significant role in the process of externalizing women's online motorcycle taxis ${ }^{16}$.

Research conducted in the city of Bandung using constructivism paradigm and phenomenological approach. They are resulting in the conclusion that the background of choosing a profession as an online motorcycle taxi driver is constructed by self-identity related to his inner motivation. On the other hand, some people have not entirely accepted female online

Online Perempuan Di Kota Malang', Jurnal Sosiologi Pendidikan Humanis, 4.2 (2016), 115-24.

15 Tania Larasati, 'Stereotipe Terhadap Perempuan Pengemudi Transportasi Umum Berbasis Online Di Jakarta Timur | Semantic Scholar' (Universitas Airlangga, 2017).

16Hilman Rizky Rafidan, 'Konstruksi Sosial Ojek Online Perempuan (Studi Tentang Ojek Online Perempuan Di Kota Surabaya)', Jurnal Sosiologi Universitas Airlangga, 8.1 (2019), 1-18. 
motorcycle taxi drivers in the city of Bandung. This condition is known from the reasons behind the online motorcycle taxi drivers in doing the job. That is, women's capabilities prove that they are capable of doing the same work and responsibilities as men.

In terms of constructing themselves in the community, online motorcycle taxi drivers change stereotypes in society. In the end, the public became responsive to the presence of female online motorcycle taxi drivers. On the other hand, female online motorcycle taxi drivers provide an alternative for consumers who feel uncomfortable if a male motorcycle taxi driver carries them. With the old stereotypes still circulating in the environment, female online motorcycle taxi drivers can show their existence and quality so that they can be equal to other online motorcycle taxi drivers, namely men. ${ }^{17}$

It can be concluded that research related to female online motorcycle taxi drivers has varied research focuses such as the social construction of fellow women online motorcycle taxi drivers, gender views of female motorcycle taxi drivers and the meaning of the online motorcycle taxi driver profession for female online motorcycle taxi drivers. The difference in the exposure of the research above has a different focus with the author's research on the context of stereotypes formed against female online motorcycle taxi drivers. In addition, there are also differences in the use of the theory used in analyzing the data. The theory chosen by the author is Alfred Schutz's Motive Theory.

${ }^{17}$ Verasatiwi and Wulan, 'Studi Fenomenologi Pengemudi Ojek Perempuan di Kota Bandung dalam Kajian Feminisme', Jurnal Acta Diurna, 14.1 (2018), 91-99.
This study aims to find out (1) How is the stereotype of female online motorcycle taxi drivers in Surakarta City (2) Who is attaching the stereotype of female online motorcycle taxi drivers in Surakarta (3) Why does the stereotype of female online motorcycle taxi drivers appear in Surakarta City?

This study used qualitative research methods. Using this method, researchers get in-depth data and can explore problems in more detail about the research problems raised. The approach that will be used in this research is phenomenology. Informants were selected based on the fulfillment of the following criteria: (1) female online motorcycle taxi drivers; (2) has been in his profession for at least two years; and (3) domiciled in the Solo Raya area. A total of 20 informants were interviewed using an indepth interview technique. The collected data is validated by the source triangulation technique ${ }^{18}$.

The first motive relates to why a person takes action to create the common situation and conditions in the future. The second motive is a retrospective view of the factors that cause a person to take specific actions. The relationship between humans and reality in social life has a close relationship or an authentic nature that is proven theoretical. By nature, humans have pragmatic motives. Namely, humans try to control, dominate or change the world to implement projects to achieve their goals. Schutz calls the "because-of-motive" motive the practical direction of action that is oriented towards the future is what Schutz calls the "because-of-motive" motive. In this case, it can be concluded that when individuals do things with what they want by

18 Earl Babbie, The Practice of Social Research (Singapore: Wadsworth Cengage Learning, 2013). 
their goals then it includes the motive "because-of-motive" or in order to motive.

The because-of-motive is an explanation of the cause of the action of the actor in question. The problem of cause in the actor's actions is motivated by past events or based on the actor's experience. So that past events can influence someone to do something.

The motive that becomes the goal clearly refers to a situation in the future where the actor wishes to achieve it through some of his actions. While the motive becomes a cause refers to a situation in the past. In this sense, the motivation will determine the actions taken by the actor. In the form of action, the actor is only aware of the motive, which is the goal and not the motive which is the cause. So that it will be realized after the actor will do the action.

\section{Discussion}

The development of an increasingly sophisticated era today impacts several things in people's lives, such as in a profession. The driver's profession is now not only done by men. The presence of technology has created an online motorcycle taxi application innovation that has made many women become online motorcycle taxi drivers. One of these can be found in the city of Surakarta.

Although many female motorcycle taxi drivers are often found, some people still stereotype women who work as online motorcycle taxi drivers. The stereotypes given to them are motivated by various factors. It can be in the personal view of the embedder and from socio-cultural factors in the community.

Of course, the women working as motorcycle taxi drivers have a motive to choose that path. The first motive relates to why a person creates the common situation and conditions in the future. They want a more comfortable job to be carried out by a woman in general, as it is realized that being an online motorcycle taxi is more often done by men. The various bases that make themselves the most dominant online motorcycle taxi drivers are economic factors. Women dominate the female online motorcycle taxi drivers in the city of Surakarta. The interest in earning more than a job makes women not reluctant to work as online motorcycle taxis.

Among them, there are those familiar with the profession as online motorcycle taxi drivers because the previously carried out profession was conventional motorcycle taxis. ${ }^{19}$ This basis makes him without thinking twice about registering as an online motorcycle taxi driver. So, carrying out the profession as an online motorcycle taxi only needs a little adaptation, such as using applications used as the primary means of working. Although I already have experience as a motorcycle taxi driver, there are still challenges. The difference experienced is in the passengers, which in the past used to be motorcycle taxi drivers. It was easier to get passengers because many of the majority of female passengers preferred female motorcycle taxis as well. So, when he started to become an online motorcycle taxi, it decreased slightly because male passengers who entered his order often canceled orders. 20

With various situations and conditions related to the economy, the online motorcycle taxi profession is one of the middle ways. Thus, the purpose of choosing a profession as an online motorcycle taxi is something that is desired with the

${ }^{19} \mathrm{Bu}$ End, Wawancara Pribadi, Rabu 8 Juli 2020.

${ }^{20} \mathrm{Bu}$ Fe, Wawancara Pribadi, Sabtu 10 Oktober 2020. 
orientation of being able to get more efficient time to be closer to family, especially caring for children. ${ }^{21}$ Another motive is that women are interested in working as online motorcycle taxi drivers because they feel that their income is more than the income from their previous job. ${ }^{22}$ Gojek drivers say that their income has increased since joining as partners by gaining access to more customers through the app. ${ }^{23}$

The second motive is a retrospective view of the factors that cause a person to take certain actions. It is not wrong if the stereotype of women is increasingly embedded in people's minds. Coupled with the influence of popular culture, where people tend to follow things that are widely followed which become popular in the community, it further strengthens the stereotype that women should be like that. ${ }^{24}$ One of the stereotypes that are pinned on female online motorcycle taxi drivers is because of the community's assumption that the motorcycle taxi profession is generally carried out by men which is risky for women because it is side by side with street life. ${ }^{25}$

Table 1. Stereotypes

\begin{tabular}{|c|l|l|c|}
\hline $\begin{array}{c}\text { Perpetra } \\
\text { tor }\end{array}$ & $\begin{array}{l}\text { Stereoty } \\
\text { pe }\end{array}$ & Context & $\begin{array}{c}\text { Female } \\
\text { Driver } \\
\text { Respons } \\
\text { e }\end{array}$ \\
\hline
\end{tabular}

${ }^{21} \mathrm{Mbak} \quad$ Oc, Wawancara Pribadi, Jumat 2 Oktober 2020.

${ }^{22}$ Mbak Ay, Wawancara Pribadi, Kamis 1 Oktober 2020.

23 Mega Swastika Junior, 'Fungsionalitas Konflik Gojek: Studi Fenomenologi Terhadap Konflik Pengemudi Gojek Di Kota Kediri', Jurnal Analisa Sosiologi, 6.1 (2017), 16-32.

${ }^{24}$ Sapta Sari, 'Stereotip, Bahasa, Dan Pencitraan Perempuan Pada Iklan Dalam Prespektif Budaya Populer', Observasi, 10.1 (2012), 13-28.

${ }^{25}$ Bunda $\mathrm{Fe}$, Wawancara Pribadi, Sabtu 10 Oktober 2020.

\begin{tabular}{|c|c|c|c|}
\hline Male drivers & $\begin{array}{l}\text { Can't take } \\
\text { care of } \\
\text { themself }\end{array}$ & $\begin{array}{l}\text { When you } \\
\text { get an } \\
\text { order at } \\
\text { night }\end{array}$ & $\begin{array}{l}\text { Not angry } \\
\text { but happy }\end{array}$ \\
\hline & $\begin{array}{l}\text { Can't take } \\
\text { care of } \\
\text { themself }\end{array}$ & $\begin{array}{l}\text { Monitore } \\
\mathrm{d} \text { when } \\
\text { delivering } \\
\text { customers }\end{array}$ & $\begin{array}{l}\text { Glad to } \\
\text { have } \\
\text { security }\end{array}$ \\
\hline \multirow[t]{4}{*}{$\begin{array}{l}\text { Female } \\
\text { driver family }\end{array}$} & $\begin{array}{l}\text { Competenc } \\
\text { e to ride a } \\
\text { motorbike }\end{array}$ & $\begin{array}{l}\text { Getting } \\
\text { impolite } \\
\text { act }\end{array}$ & $\begin{array}{l}\text { Convince } \\
\text { d that she } \\
\text { can }\end{array}$ \\
\hline & $\begin{array}{l}\text { Can't take } \\
\text { care of } \\
\text { themself }\end{array}$ & $\begin{array}{l}\text { Physical } \\
\text { strength } \\
\text { unlike } \\
\text { men }\end{array}$ & $\begin{array}{l}\text { Taking } \\
\text { other } \\
\text { people's } \\
\text { opinions }\end{array}$ \\
\hline & $\begin{array}{l}\text { Social scope } \\
\text { as a driver }\end{array}$ & $\begin{array}{l}\text { Side by } \\
\text { side with } \\
\text { stranger in } \\
\text { the street }\end{array}$ & $\begin{array}{l}\text { Make sure } \\
\text { she can } \\
\text { take care } \\
\text { of herself }\end{array}$ \\
\hline & $\begin{array}{l}\text { Lack of } \\
\text { understandi } \\
\text { ng of the } \\
\text { field }\end{array}$ & $\begin{array}{l}\text { Doubt the } \\
\text { wife's } \\
\text { expertise } \\
\text { in using a } \\
\text { motorbike }\end{array}$ & $\begin{array}{l}\text { Convince } \\
\text { d that she } \\
\text { can }\end{array}$ \\
\hline \multirow[t]{2}{*}{$\begin{array}{l}\text { Male } \\
\text { customer }\end{array}$} & $\begin{array}{l}\text { Riding skill } \\
\text { competence }\end{array}$ & $\begin{array}{l}\text { Male } \\
\text { customer } \\
\text { to help } \\
\text { ride the } \\
\text { bike }\end{array}$ & $\begin{array}{l}\text { Happy, } \\
\text { not angry }\end{array}$ \\
\hline & $\begin{array}{l}\text { Competenc } \\
\text { e in the } \\
\text { profession }\end{array}$ & $\begin{array}{l}\text { Not } \\
\text { suitable as } \\
\text { a driver }\end{array}$ & $\begin{array}{l}\text { Convince } \\
d \text { that she } \\
\text { can }\end{array}$ \\
\hline \multirow[t]{2}{*}{$\begin{array}{l}\text { Women } \\
\text { costumer }\end{array}$} & $\begin{array}{l}\text { Lack of } \\
\text { understandi } \\
\text { ng of the } \\
\text { field }\end{array}$ & $\begin{array}{l}\text { When } \\
\text { crossing a } \\
\text { pothole }\end{array}$ & $\begin{array}{l}\text { Don't like } \\
\text { it because } \\
\text { it's } \\
\text { canceled }\end{array}$ \\
\hline & $\begin{array}{l}\text { Riding skill } \\
\text { competence }\end{array}$ & $\begin{array}{l}\text { Won't last } \\
\text { long as a } \\
\text { driver }\end{array}$ & $\begin{array}{l}\text { Convince } \\
\text { d that she } \\
\text { can }\end{array}$ \\
\hline
\end{tabular}

Stereotypes tend to display false ideas that lead to negative judgments or even demeaning others. ${ }^{26}$ Stereotypes are based

${ }^{26}$ Dian Lestari and Wirdanengsih Wirdanengsih, 'Stereotip Terhadap Perempuan Penyandang Disabilitas Di Kota Padang (Studi Pada Perempuan Penyandang Disabilias Daksa Di DPC 
on interpretations generated based on perspectives and cultural backgrounds, resulting from communication with other parties and not from direct sources. The stereotypes pinned by people are based on some people who do not believe that women can carry out the profession as online motorcycle taxis. Women who are echoed by the feminine nature are closely related to domestic work. Like women, it is not appropriate to work in a scope that men generally do. So, sometimes female drivers are canceled because male customers are less willing to ride with women, especially mothers. ${ }^{27}$ The anchors reasoned that they were not comfortable when they were riding with women, and also because it was not appropriate to take care of themselves as a Muslims when they were riding with other women.

The influence of socio-culture is also the basis for thinking someone puts stereotypes on something in other people. The existence of women in the domestic space makes the assumption of women as the second human, especially in married life. It is due to the assumption that women's abilities and reasoning are less perfect than men's. ${ }^{28}$ Stereotypes on online motorcycle taxi drivers arise because of the assumption by some people that men are closely related to masculine traits while women are feminine. Thus, the realm of work as a driver who in society is closely related to masculine or men makes the appearance of

PPDI Kota Padang)', Jurnal Prespektif: Jurnal Kajian Sosiologi Dan Pendidikan, 3.2 (2020), 262-71 <https://doi.org/https://dx.doi.org/10.24036/persp ektif.v3i2.249>.

${ }^{27}$ Bunda Fe, Wawancara Pribadi, Sabtu 10 Oktober 2020.

28 Hoiril Sabariman, 'Perempuan Pekerja (Status Dan Peran Pekerja Perempuan Penjaga Warung Makan Kurnia)', Jurnal Analisa Sosiologi, 8.2 (2019), 162-75. male stereotypes on women and not the basics of their work. ${ }^{29}$

Personality stereotypes make men able to do activities outside the home or public space, while women can only do activities inside the home or domestic space. ${ }^{30}$ Even though economically, the opportunity for women to become online motorcycle taxi drivers is one way to reduce unemployment among women in Indonesia.

Stereotypes that arise from fellow online motorcycle taxi drivers are based on events experienced by female drivers at work. At some points in the online ojek base, female drivers often work late into the night. This makes fellow online motorcycle taxis feel sorry for being afraid of their safety. ${ }^{31}$ Stereotypes are needed to generalize perception, but stereotypes are prejudices about a group of people that affect the perception and interpretation of the data that has been received. ${ }^{32}$ Basically the male drivers support their female motorcycle taxi partners. However, unwittingly by the female drivers they are accepting a stereotype. Not infrequently, male drivers often provide input to them regarding their safety at work. Like when the female drivers were at the base. Because they often move from place to place to get orders, female drivers are often located at bases far from their friends at the main base or base camp. From this, male drivers who are more

${ }^{29} \mathrm{Mbak}$ Oc, Wawancara Pribadi, Jumat 2 Oktober 2020.

30 Nirmala Khairunnisa Budi, 'Stereotip Perempuan Dalam Cerita Pendek "A Story for Children" Karya Svava Jakobsdottir', Journal of Chemical Information and Modeling, 3.2 (2020), 220-30.

${ }^{31}$ Mas Sya, Wawancara Pribadi, Rabu 8 Juli 2020.

${ }^{32}$ Ismiati, 'Pengaruh Stereotype Gender Terhadap Konsep Diri Perempuan', Jurnal Studi Gender Dan Islam Serta Perlindungan Anak, 7.1 (2018), 33-45. 
socially older are often motivated to get carried away working late at night. It was conveyed because her colleague was worried about the safety of the female drivers, especially for those who are not yet old enough who are vulnerable to the dangers of crime that leads to sexuality.

Other forms of stereotypes are not only embedded from the community but also in fellow drivers. On average, men put stereotypes on female drivers because women's driving skills are not the same as men's motives. So, it is doubtful when get an order to deliver, it's not uncommon to get a rejection like being canceled by a male customer. ${ }^{33}$ Another form of stereotype is the lack of trust in the driving ability of the female driver, so that sometimes the male customer drives the motorbike during the trip. This stereotyped view then obscures the view of humans personally, because it includes every type of human being in the stereotype box. $^{34}$

At first, the female drivers ignored what happened to them, such as being canceled, but now this has become a concern for the female driver and fellow online motorcycle taxi drivers because it greatly affects the profession, especially in getting orders. After all, they have received direct sanctions in the application. Moreover, not all customers who cancel their orders in the application are willing to apologize if they have canceled the driver voluntarily. ${ }^{35}$

Stereotypes are pinned by fellow drivers if at night female drivers still work to deliver passengers. This is considered risky

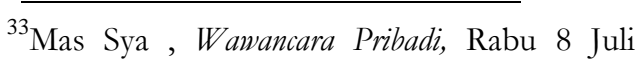
2020.

${ }^{34}$ Esti Zaduqisti, 'Stereotip Peran Gender Bagi Pendidikan Anak', Muwazah, 1.1 (2009), 73-82.

${ }^{35} \mathrm{Bu}$ End, Wawancara Pribadi, Rabu 8 Juli 2020. and dangerous for him. Even though the stereotype that appears is empathy for female drivers by accompanying their journey when dropping off passengers or monitoring via online in the application to ensure their safety. ${ }^{36}$ However, the female driver did not realize that she had received stereotypical treatment in the form of positive actions from other fellow drivers, especially male drivers.

The process of stereotyping oneself does not just appear when a human is an adult, but takes place from an early age which parents and their environment fear. ${ }^{37}$ This is shown from the family of the driver himself. A concern experienced by the driver's family actually shows the existence of a form of stereotypes such as from parents and husbands. They do not just permit women who want to be drivers. In the dialogue process, there is a depiction of a stereotype such as being afraid that the job of being a driver is too heavy, a risk to personal safety and prone to crime. The attitude shown actually leads to the weakness of the driver. Like the example of the husband who is worried if a crime occurs that the female driver can't handle herself.

The perception of online motorcycle taxi drivers towards other female drivers is never a problem even though motorcycle taxi drivers are identical to men's work because as long as the work they do is positive and can help each other, this is not a problem. It is proper to support each other as fellow drivers, not bring them down because everyone's sustenance has their share. They consider this a form of gender equality where women can do matching jobs

${ }^{36} \mathrm{Mbak}$ Ay, Wawancara Pribadi, Kamis 1 Oktober 2020.

${ }^{37}$ Suyanto, 'Faktor Sosil Dan Penyebab Stereotip Perempuan Dalam Bahasa Indonesia Dalam Ranah Rumah Tangga', 34.1 (2010), 23-40. 
to men's. Some women choose to form a community of female online motorcycle taxi drivers as a form of existence for women who are drivers, but some others also choose not to join these communities because they prefer to gather with their families after work.

The view of male online motorcycle taxi drivers towards female drivers is not much different from the previous view that they will still support each other as long as nothing negative is done. Several male drivers admitted that they were amazed and applauded by the women who work hard to become the backbone of the family to earn a living for their children, even in a way that men usually do. The form of support is usually in the form of light greetings when meeting fellow drivers on the road or when resting while waiting for orders to arrive. Although on the other hand, the male driver has unwittingly given a stereotype to female drivers by taking into account their ability to drive, concerns about their safety when dropping off male customers, especially in the afternoon or evening.

Stereotypes are more about the meaning of labeling another person or group, including their attitudes and behavior towards them. At the same time, the views of the community or customers towards female online motorcycle taxi drivers are a form of progress for women with independent and hardworking nature so that they close the public's eyes on women who tend to be known to be gentle and choose to stay at home and take care of children. Also, they work as parents responsible for the survival of their families amid globalization which has developed rapidly. In addition, amid this hard job competition, there are still women who are able to survive and even win this competition. Of course, with the development of increasingly sophisticated technology, it is hoped that it can grow many jobs for the entire world community.

Stereotypes are part of a culture that includes symbols, beliefs, and values. Certain behavioral systems influence stereotypes. Stereotypes are also a social component of society that are usually used by certain groups and result from conflicts and power relations rather than the characteristics of something or someone itself. Masculinity and femininity are also part of this stereotype. Men value "competence" as part of masculinity, and women value "warmth" and "expressiveness" as part of femininity.

This type of work is not much in demand by women because it is considered manual work that is identical to men. The cultural construction inherent in the automotive world as a men's world is a product of the socio-cultural construction of society. Automotive is a masculine thing because it relates to a masculine object's techniques, machines, and work. Automotive describes the traits that should be attached to men, strong, rational, manly and mighty. Therefore women who are weak, emotional, motherly and natural are considered unfit to be in this field of work.

\section{Conclusion}

A job as an online motorcycle taxi that is now starting to be in great demand by women has received various responses in stereotypes. Stereotypes emerge through various contexts, both directly from online motorcycle taxi drivers and culturally in the community.

The stereotype given to female online motorcycle taxi drivers stems from women who have their own motives for working as online motorcycle taxi drivers. Their underlying motives are to have additional income rather than being unemployed, previously had experience as a motorcycle 
taxi driver before there was an online motorcycle taxi and saw a large income opportunity from the profession they were living.

From the motive that has the desire to be oriented towards the future of the female motorcycle taxi drivers, which makes other people respond to their profession in a stereotyped manner. Those who pinned stereotypes on them as well as from their own families for reasons of concern for their safety as well as their ability or skill in driving a vehicle on the road. The male online motorcycle taxi drivers also give such a stereotype because they are worried about delivering customers. Another motive is that customers think women are not worthy to carry out this profession because men generally do it.

\section{Daftar Pustaka}

\section{Journal}

Budi, Nirmala Khairunnisa, 'Stereotip Perempuan Dalam Cerita Pendek "A Story for Children" Karya Svava Jakobsdottir', Journal of Chemical Information and Modeling, 3 (2020), 220 30

Ismiati, 'Pengaruh Stereotype Gender Terhadap Konsep Diri Perempuan', Jurnal Studi Gender Dan Islam Serta Perlindungan Anak, 7 (2018), 33-45

Junior, Mega Swastika, 'Fungsionalitas Konflik Gojek: Studi Fenomenologi Terhadap Konflik Pengemudi Gojek Di Kota Kediri', Jurnal Analisa Sosiologi, 6 (2017), 16-32

Kurniawan, Faisal, Siti Fatimah Soenaryo, 'Menaksir Kesetaraan Gender Dalam Profesi Ojek Online Perempuan Di Kota Malang', Jurnal Sosiologi Pendidikan Humanis, 4 (2016), 115-24
Lestari, Dian, and Wirdanengsih Wirdanengsih, 'Stereotip Terhadap Perempuan Penyandang Disabilitas Di Kota Padang (Studi Pada Perempuan Penyandang Disabilias Daksa Di DPC PPDI Kota Padang)', Jurnal Prespektif: Jurnal Kajian Sosiologi Dan Pendidikan, 3 (2020), 262-71 $<$ https://doi.org/https://dx.doi.org/1 0.24036/perspektif.v3i2.249>

Rafidan, Hilman Rizky, 'Konstruksi Sosial Ojek Online Perempuan (Studi Tentang Ojek Online Perempuan Di Kota Surabaya)', Jurnal Sosiologi Universitas Airlangga, 8 (2019), 1-18

Rahmawati, Rita, Shinta Dewi Rismawati, and Esti Zaduqisty, 'Sistem Pengupahan Dan Pembagian Kerja Perempuan Buruh Batik Berbasis Putting out System Di Kota Pekalongan (Proses Dan Implikasi Marginalisasi Terhadap Perempuan Buruh Batik)', Research Journal, 10 (2013), 274-93

Sabariman, Hoiril, 'Perempuan Pekerja (Status Dan Peran Pekerja Perempuan Penjaga Warung Makan Kurnia)', Jurnal Analisa Sosiologi, 8 (2019), 162-75

Sari, Sapta, 'Stereotip, Bahasa, Dan Pencitraan Perempuan Pada Iklan Dalam Prespektif Budaya Populer', Observasi, 10 (2012), 13-28

Sharp, Joanne, John Briggs, Hoda Yacoub, and Nabila Hamed, 'Doing Gender Development: Empowerment Understanding Relations Gender', Transactions of the Institute of British Geographers, 28 (2003), 281-95

Siti Arofah, Alif Fadzilatus, and Yus'afin Taji Alam, 'Eksistensi Driver Ojek Online Wanita Sebagai Bentuk Kesetaraan Gender', Jurnal Sosiologi Nusantara, 5 (2019), <https://doi.org/10.33369/jsn.5.2.171 $-183>$ 
Suyanto, 'Faktor Sosil Dan Penyebab Stereotip Perempuan Dalam Bahasa Indonesia Dalam Ranah Rumah Tangga', 34 (2010), 23-40

Tumimbang, Gladys N, Suwu, Evie A A, and Juliana Tumiwa, 'Kajian Gender Tentang Pengemudi Go-Jek Wanita Di Kota Manado', Jurnal Holistik, 13 (2020), 1-16

Verasatiwi, Irma, and Roro Retno Wulan, 'Studi Fenomenologi Pengemudi Ojek Online Perempuan Di Kota Bandung Dalam Kajian Feminisme', Journal Acta Diurna, 14 (2018), 91-99 https://doi.org/10.20884/1.actadiurn a.2018.14.1.1145.

Wiratno, Tri, Atik Catur Budiati, and Siany Indria Liestyasari, 'Strategi Penerapan Pendidikan Politik Sebagai Upaya Peningkatan Partisipasi Politik Di Kalangan Mahasiswa (Kajian Fenomenologi Mahasiswa Fkip Uns Tahun 2016/2017)', Sosialitas: Jurnal Ilmiah Pendidikan Sosiologi-Antropolog, 2015

Zaduqisti, Esti, 'Stereotip Peran Gender Bagi Pendidikan Anak', Muwazah, 1 (2009), 73-82

\section{Books}

Babbie, Earl, The Practice of Social Research (Singapore: Wadsworth Cengage Learning, 2013).

Suyanto, B, and E S Hendarso, Wanita Dan Subordinasi Dan Marinalisasi Menuju Ke Pemberdayaan (Surabaya: Airlangga University Press, 1996)

Turner, Bryan S, The Cambridge Dictionary of Sociology, ed. by Bryan S Turner (New York: Cambridge University Press, 2006)

\section{Article and Newspaper}

Amalia, Yunita, 'Pengemudi Ojek Online, Terpinggirkan Karena Perempuan',
2017

<https://www.merdeka.com/peristiwa /pengemudi-ojek-online-terpinggirkankarena-perempuan.html>

Ant, 'Ojek Online Dilarang Beroperasi Di Solo', News.Okezone.Com, 2016

Arifin, Ridwan, 'Sedih! Driver Ojol Suka Ditolak Hanya Karena Wanita', Oto.Detik.Com, 2018

International Labour Office, World Employment Social Outlook: Trends for Women 2018 Global Snapshot, International Labor Organization, 2018 <http://www.ilo.org/wcmsp5/groups /public/---dgreports/---dcomm/--publ/documents/publication/wcms_6 19577.pdf>

Kanedi, 'Ketika Pengemudi Ojek Online Perempuan Di-'Cancel' Penumpang Lelaki', Www.Watyutink.Com, 2017

Larasati, Tania, 'Stereotip Terhadap Perempuan Pengemudi Transportasi Umum Berbasis Online Di Jakarta Timur'

Walfajri, Maizal, 'Jumlah Mitra Pengemudi Perempuan Grab Indonesia Tumbuh Lima Kali Lipat', Industri.Kontan.Co.Id, 2018

World Bank, 'Labor Force Participation Rate, Female (\% of Female Population Ages 15-64) (Modeled ILO Estimate) Indonesia', 2020 $<$ https://data.worldbank.org/indicator /SL.TLF.ACTI.FE.ZS?locations=ID $>$ 